\title{
HEALTH AS AN ECONOMIC DIMENSION: A COMPARATIVE STUDY OF INDIA AND CHINA
}

\author{
Manju Yadav \\ RRBMU University, India \\ Correspondence: manjuyadav521@gmail.com
}

\begin{abstract}
In modern era, human resource is a crucial factor for economic development. Several studies reveal that rapid economic growth of developed countries has been linked with investment in human capital. Efficient and proper management of the workforce is an important factor in development of a country. The importance of human capital formation is now fully recognized because healthy and skilled people, along with physical capital, help in capital formation and raising economic growth. Therefore, large scale investment in human capital is required for the full and optimum use of natural resources. Improvement in the health of masses increases their productive capacity and leads to quantitative improvement in human capital. This paper examines the role of health facilities in human capital formation as well as in economic development. The current study analyzes the trends of current health expenditure as percent of GDP in India and China. An effort has been made to compare the impact of health expenditure on value added per worker in agriculture and its allied sectors in India and China by employing multiple regression model using data from 2000 to 2017. Findings reveal that independent variable (current health expenditure) explains the variation in dependent variable (value added per worker) to an extent of $37.9 \%$ and $56.9 \%$ in India and China, respectively.
\end{abstract}

\section{KEYWORDS}

Health, Expenditure, GDP, Value added, Regression, India, China,

\section{INTRODUCTION}

The concept of human capital formation is of recent origin. Traditionally, more importance has been placed on the accumulation of physical capital to achieve economic development. Earlier economists like Adam Smith, Veblen, and Marshall had also emphasized the criticality of human capital formation in the production process. The UN charter on Human Rights (1948), envisages the right of primary education and primary health as a human right. It follows, therefore, that every child born in the country must have an assurance of good health, education, and prosperity. Education and health are the primary inputs in the development of human resource. Education helps in developing necessary skills and abilities, thus boosting productivity. Health is an equally important constituent of well-being and foundation of prosperity. Good health is central to human happiness. It also contributes to economic progress, as healthy populations live longer, are more productive, and save more (WHO).[1] In developing and underdeveloped countries like India and other BRICS (Brazil, Russian Federation, India, China and South Africa) nations, the population is illiterate, unskilled, diseaseridden, and superstitious, which acts as a barrier to growth rather than a facilitator. III health is considered as a huge financial burden, and it is the major cause of 50 percent of the growth differential between developed and developing countries. [2]

According to WHO's health score (2016), India's position (43) is the lowest among low income South Asian countries like Nepal, Bangladesh and Sri Lanka. Among BRICS nations, it is placed after Brazil (78) and China (72).[3] There are major differences in the ability of the BRICS nations to 
increase the investment on health, China saw an increase of $2 \%$ in its devoted share of GDP to health in the period extending from 1995 to 2013, whereas India saw it contract from $4.06 \%$ to $3.97 \%$. [4 ] It has been evidenced that there is a positive relation between investment in human capital and GDP growth rate, countries which had spent more on human capital during 1990-2016 recorded $1.1 \%$ higher annual growth rate in comparison to others. This positive correlation suggests that nations failing to invest in health and education are at risk of stagnating economies and lower per capita income.

Therefore, large scale investment in human capital is required for the full and optimum use of natural resources. Improvement in the health of masses increases their productive capacity and leads to quantitative improvement in human capital. Mainstream economists, therefore, consider expenditure on health services as a significant means to enhance productive capacity and productivity of human beings. Investing in people is the best way to achieve sustainable development goals. [3] The repercussions of meagre health conditions on workers productivity are well recognized. India has the highest population of children stunted (low height for age) due to malnutrition, at 48.2 million. Stunted children will be less healthy and productive for the rest of their lives, and countries with high rates of stunting will be less prosperous.[5] Thus, investment in social infrastructures like education and health becomes essential in promoting growth and standard of living. It is the quality of human resource that ultimately determines the success of all development policies. Healthier population is a major source of capital accumulation which boosts savings and enhances productivity. [6]

\section{REVIEW OF LITERATURE}

Ullah Saif.et.al. (2019) examined the role of health status on workers' productivity (1980 to 2010) by employing Auto Regressive Distributed Lag (ARDL) approach by Pesaran and Shin (1999) and Pesaran et al. (2001) for Pakistan. For every $1 \%$ improvement in health status, $13.39 \%$ increase in workers' productivity was noted. In comparison, the coefficient of education indicates that worker productivity will increase by $0.18 \%$ for every $1 \%$ increase in education. Furthermore, the study found "Inflation has negative relationship with worker productivity whereas the association between worker productivity and Foreign
Direct Investment, being proxy of technology transfer, is positive but statistically insignificant". [7]

Mohammadzadeh, et.al. [8] examined the relationship between gross domestic product (GDP) and labor productivity in Iran using time series data for the period of 1951-1994. Due to the long-term nature of the effect of health expenditure on labor productivity, JohanssonJuselius co-integration has been used. The results indicate that one percent increase in per capita expenditure of health improves 0.36 percent productivity of labor force. Furthermore, the study found that with coefficients of 0.41 and 0.09, expenditures on education and physical per capita also have a positive and significant effect on labor productivity. [8]

Wang [9] examines the optimal level of health expenditure for maximizing economic growth for Organization for Economic Co-Operation and Development (OECD) countries, using the data from 1990 to 2009. The analysis was carried out by employing Generalized Method of Moments (GMM). The study confirmed that when the ratio of health spending to gross domestic product (GDP) is less than the optimal level of $7.55 \%$, increase in health spending effectively leads to better economic performance. Additionally, the study suggests that any expenditure over and above this optimal level is not associated with better care or an improved economic performance. Therefore, appropriate spending on health care supports economic development.

Feng Wei, et.al. [10] evaluate the effect of government health spending on labor productivity of agricultural and non-agricultural labor from the perspective of brain cognition in China, using the data from 2007-2013. The findings advocate that public health expenditure is helpful in improving labor productivity and plays a significant role in promoting productivity of both agricultural and nonagricultural workers. It also shows that in less developed areas, increased public health expenditure can improve mental health of the people and enhance efficiency by improving people's thought-process. It is highlighted that in rural areas with scarce infrastructure, excessive health investment can squeeze out physical capital investment. This is particularly important as adequate infrastructure is a necessity for the effective utilization of public health expenditure. 10

Serge, M. et.al.[11] have analyzed the association between health status and growth rate (from 1995 to 2015) 
for African countries. Results show that there is cointegration between health expenditures and economic growth. The findings suggest that the countries should try to increase their revenue by raising taxes on cigarettes and other products of ostentation, in order to increase investment in health services.

Dormont, et.al [12] investigates the association among health care expenditure, medical innovations, health status, growth and welfare. The study also investigates empirically the relation between GDP growth and health spending for the US, EU-15 and Japan, employing a projection method. It estimates an amount of total aggregate expenditure for that could be channeled to the health sector up to 2050. Results examines that health spending triggers technological progress, which is a potential source of better outcomes in terms of longevity and quality of life. Which later contributes to GDP per capita through higher participation of labor force and higher labor productivity.[12]

Ercelik G.[13] examines the relationship between health expenditure and economic development (from 1980 to 2015) in Turkey. The researcher has used Autoregressive distributed lag bound test model to analyze the association between health care expenditure (\% of GDP) and GDP per capita. The results reveal that the variables are cointegrated and in the long run there is a significant relationship between health care expenditure and GDP per capita.[13]

Sarkar, et.al. [14] identified the impact of ill health on the productivity, earning, and health expenditure of the informal sector workers in Bangladesh. A cross-sectional survey was conducted among three occupational groups of informal workers (rickshaw pullers, shopkeepers and restaurant workers) that were generally found in all urban areas in Bangladesh. A total of 557 informal workers were surveyed for this study. About $90 \%$ of the workers included in the study were below 45 years of age, representing a population spending little on their healthcare. These costs would be much greater in higher age groups, since healthcare costs increase with higher age. Results shows a high correlation among health and productivity of the workers. The study estimates an overall loss of $28.5 \%$ earnings in all three groups, whereas, due to sickness absenteeism, the losses of shopkeepers and rickshaw pullers were $30.5 \%$ and $30.2 \%$, respectively. [14]
Isreal, A. et.al. [15] have analyzed the impact of health capital on Total-Factor Productivity (TFP) in Singapore from the period of 1980-2013. The finding from the Autoregressive Distributed Lag (ARDL) bound test shows that there is stable and long run co-integration between TFP, health capital, and education. The long run estimate shows that health capital and education make a positive and substantial contribution to TFP. This indicates that the TFP of Singapore could be substantially improved if spending on health capital and education are increased accordingly.[15]

Mathew \& Neumayer [16] have illustrated the link between poor health and total factor productivity for 52 developed and developing countries, from 1965 to 1996. For the investigation, the author selects three main indicators: the proportion of undernourished within a country, the incidence of malaria and other waterborne diseases, and life expectancy. Findings of the study show a negative relation between the ill health and total factor productivity of the workers.[16]

Arun \& Kumar D. [17] in their research 'Public health expenditure in BRICS countries- an empirical analysis' discuss, that while per capita public health expenditure increases significantly (from Rs. 24.26 to Rs. 157.18) in between 2000-01 to 2010-11, the percentage share of health expenditure to the GDP shows but a small increase (from 0.13 percent to 0.26 percent) in the same period, not stepping up with public health requirements. Many studies claimed a highly significant and positive relation between per capita public health expenditure and per capita GDP, the health care facilities remain inadequate whereas the access to them varying across countries. The study further concludes that BRICS nations need to increase their budgetary allocation on health to catch up with high-level health standards of developed countries.[17]

Isaksson [18] (2007) studied the relationship between health status and total factor productivity, particularly in developing countries between 1990 to 2005.The study identifies many factors viz. education, health, infrastructure, imports, institutions, openness, competition, financial development, geographical predicaments and absorptive capacity, which influence total factor productivity. It was observed that TFP is influenced directly by health and indirectly by labor productivity, savings and investment. Findings advocate increasing investment in human capital.[18] 
Bekedam [19] WHO Representative addressing health Sabha in 2016, said that without commensurate progress in human development achieving a high growth rate is a dream for any nation. Among the BRICS group, India spends nearly 2.5 times less than other nations. Due to this low expenditure, India's health indicators such as life expectancy are even lower than less developed economies. Many factors are responsible for the grim status of these health indicators, but the leading cause is a lowlevel investment in health. In 2016, with a health score of 43 , India was placed at the bottom among low income South Asian countries like Nepal, Bangladesh and Sri Lanka. Among BRICS nations, its place comes after both Brazil (78) and China (72). It is envisaged that "Investing in Health is Investing in India's Growth." Thus, health expenditure is crucial to increasing labor productivity which further induces growth and development.[19]

Muysken et.al. [20] investigate the relationship between per capita income and health status in U.K. This study shows a positive relationship between health status and per capita output using the standard neo-classical growth framework where the health status is exogenously given. The study also examines the effect of 'optimal expenditure on health care' on steady state growth and transition dynamics.[20]

\section{OBJECTIVES}

The primary purpose of this research is to examine the trend of current health expenditure in India and China (2000 to 2017). The study also tries to establish the relationship between current health expenditure (as percent of GDP) and value added per worker in agriculture and its allied sectors in both the countries.

\section{METHODOLOGY}

This article uses secondary data collected from the World Health Organization website (www.who.int/gho/healthfinancing), Global Health database (apps.who.int/nha/database) and World development indicators, World bank. Data relating to current health expenditure (as percent of GDP) and value added per worker in agriculture and its allied sectors in India and China has been studied through regression analysis (2000 to 2017).

\section{TRENDS OF CURRENT HEALTH EXPENDITURE (AS PERCENT OF GDP) IN INDIA AND CHINA:}

The importance of human capital formation is now fully recognized because healthy and skilled people, along with physical capital, help in capital formation and inducing economic growth. Suboptimal health facilities, skills and knowledge deficit limit the capacity to utilize the available stock of physical capital resulting in a lower growth rate in underdeveloped and developing countries.

FIGURE 1 TREND OF CURRENT HEALTH EXPENDITURE AS PERCENT OF GDP

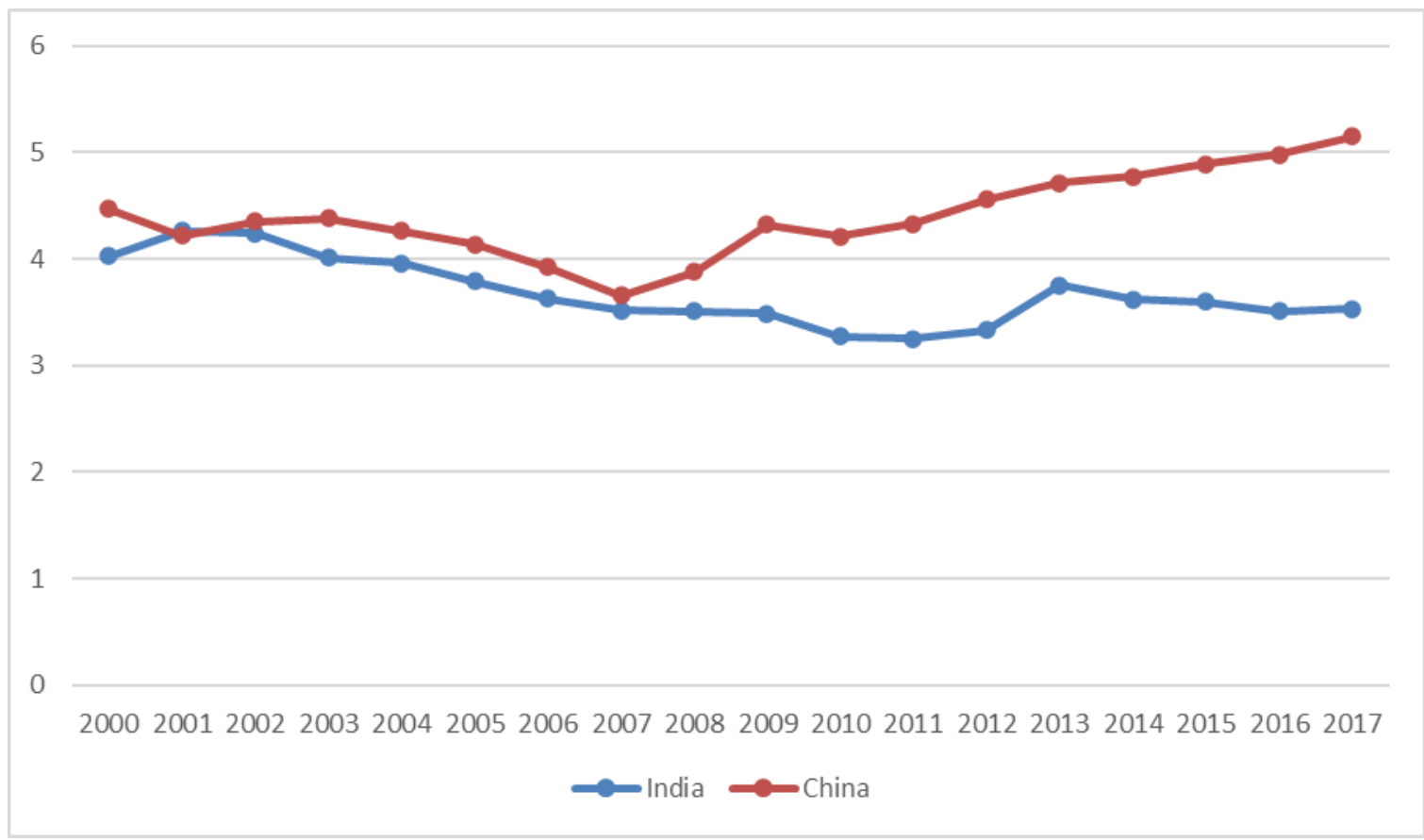


TABLE 1. TREND OF CURRENT HEALTH EXPENDITURE AS PERCENT OF GDP IN INDIA AND CHINA.

\begin{tabular}{|c|c|c|}
\hline YEAR & INDIA & CHINA \\
\hline 2000 & 4.03 & 4.47 \\
\hline 2001 & 4.26 & 4.22 \\
\hline 2002 & 4.24 & 4.35 \\
\hline 2003 & 4.01 & 4.38 \\
\hline 2004 & 3.96 & 4.26 \\
\hline 2005 & 3.79 & 4.14 \\
\hline 2006 & 3.63 & 3.92 \\
\hline 2007 & 3.52 & 3.66 \\
\hline 2008 & 3.51 & 3.88 \\
\hline 2009 & 3.49 & 4.32 \\
\hline 2010 & 3.27 & 4.21 \\
\hline 2011 & 3.25 & 4.33 \\
\hline 2012 & 3.33 & 4.56 \\
\hline 2013 & 3.75 & 4.71 \\
\hline 2014 & 3.62 & 4.77 \\
\hline 2015 & 3.6 & 4.89 \\
\hline 2016 & 3.51 & 4.98 \\
\hline 2017 & 3.53 & 5.15 \\
\hline
\end{tabular}

Source: Global Health Observatory Data Repository, WHO (apps.who.int/nha/database)21

Table -1 \& Figure -1 shows an increasing trend in current health expenditure in China, $4.47 \%$ to $5.15 \%$ during the period 2000 to 2017 . In India, the current health expenditure decreased from $4.03 \%$ to $3.53 \%$ in the same period. Until 2007, China also has a decreasing trend from $4.47 \%$ to
$3.66 \%$ but the current health expenditure in China has risen steadily since 2008 from $3.88 \%$ of GDP to $5.15 \%$ of GDP in 2017. India's health expenditure, on the other hand, is continuously decreasing with a minor variation. 
TABLE 2. TRENDS IN AGRICULTURE, FORESTRY, AND FISHING, VALUE ADDED PER WORKER (CONSTANT 2010 US\$)

\begin{tabular}{|l|l|l|}
\hline YEAR & INDIA & CHINA \\
\hline 2000 & 936.4 & 1075.99 \\
\hline 2001 & 978.39 & 1104.24 \\
\hline 2002 & 901.23 & 1129.15 \\
\hline 2003 & 971.43 & 1170.89 \\
\hline 2004 & 963.93 & 1288.55 \\
\hline 2005 & 999.81 & 1408.49 \\
\hline 2006 & 1037.72 & 1541.45 \\
\hline 2007 & 1106.86 & 1658.08 \\
\hline 2008 & 1113.61 & 1798.21 \\
\hline 2009 & 1121.72 & 1943.05 \\
\hline 2010 & 1239.99 & 2097.23 \\
\hline 2011 & 1374.92 & 2294.87 \\
\hline 2012 & 1453.3 & 2475.27 \\
\hline 2013 & 1520.5 & 2739.17 \\
\hline 2014 & 1505.8 & 3024.81 \\
\hline 2015 & 1506.65 & 3236.34 \\
\hline 2016 & 1589.11 & 3442.24 \\
\hline 2017 & 1662.34 & 3678.32 \\
\hline
\end{tabular}

Source: World Development Indicators, World Bank.[22]

FIGURE 2. TRENDS IN AGRICULTURE, FORESTRY, AND FISHING, VALUE ADDED PER WORKER (CONSTANT 2010 US\$)

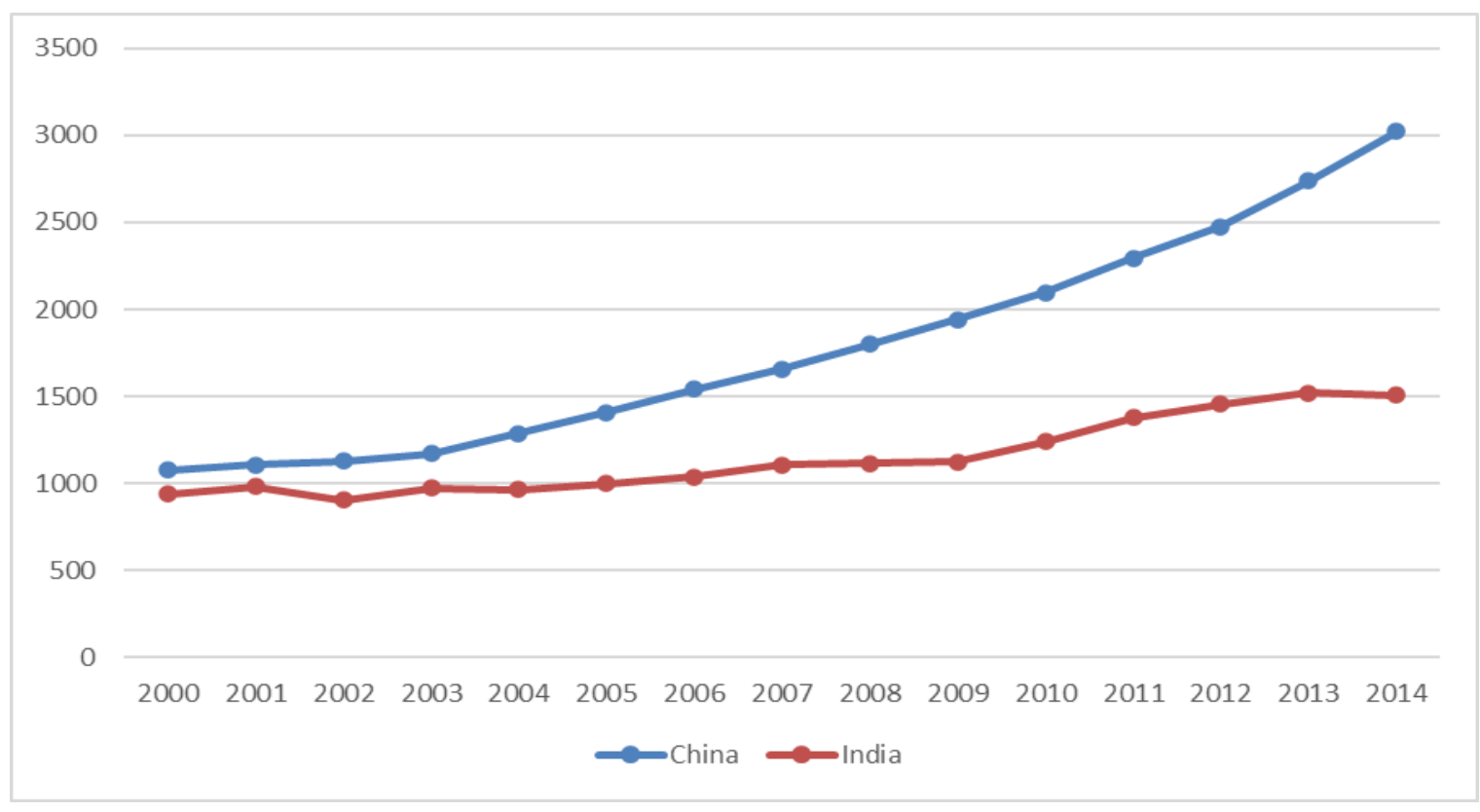


Table -2 and figure -2 display the trends of value added per worker in agriculture and its allied sectors in India and China, showing a significant relation between health expenditure and value added per worker. In the year 2000, value added per worker was 936.4 and 1075.95 for India and China, respectively. Valve added per worker shows an increasing trend during the entire period for both nations, but the rate of growth is relatively higher in China when compared to India where it rises more than threefold, jumping from 1075.95 to 3664.76 during 2000 to 2017 whereas India's sees only a less than twofold increase during the same period.

This indicates that better public health ecosystem in a country increases the productivity of its people. China, where current health expenditure is higher, houses healthier people who work more efficiently when compared to India. Therefore, expenditure on health is essential for building and maintaining a productive labor force. The general health of the workers in India is feeble resulting in a lower working efficiency. The main reasons for poor health in India are lack of nutritious diet, inadequate medical care and subpar sanitation facilities.

\section{HYPOTHESES:}

HO1: - current health expenditure as percent of GDP does not have any relation with value added per worker in India and China.

\section{TESTING OF HYPOTHESES:}

For testing this hypothesis, data related to current health expenditure as percent of GDP are collected from Global Health Observatory Data Repository, World Health Organization and data linked with value added per worker (constant 2010 US\$) in agriculture, forestry, and fishing from World bank development indicators, World Bank. Furthermore, data relating to current health expenditure (as percentage of GDP) and value added per worker (constant 2010 US\$) in agriculture, forestry, and fishing, for the period from 2000 to 2017 was placed to regression analysis.

TABLE 3: RESULT SUMMARY

\begin{tabular}{|l|l|l|}
\hline $\begin{array}{l}\text { REGRESSION } \\
\text { STATISTICS / } \\
\text { COUNTRIES }\end{array}$ & INDIA & CHINA \\
\hline OBSERVATIONS & 18 & 18 \\
\hline MULTIPLE R & 0.616 & 0.754 \\
\hline R SQUARE VALUE & 0.379 & 0.569 \\
\hline F VALUE & 9.782 & 21.139 \\
\hline P VALUE & 6.49 E-03 & 2.97 -04 \\
\hline REMARKS & Significant & Significant \\
\hline
\end{tabular}

Source: Author's calculation

The result table (Table-3) reveals that India and China both have a significant relationship between current health expenditure and value added per worker. In India and China, the correlation coefficient is .616 and .75, respectively.
In the regression analysis, the independent variable (current health expenditure) explains the variation in dependent variable (value added per worker) to an extent of $37.9 \%$ and $56.9 \%$ in India and China, respectively. $P$ value for India (.006) and China (.0002) are less than alpha value (.05), which shows significant relationship between the two 
variables. Hence, the null hypothesis that there exists no relation between current health expenditure and value added per worker is rejected for both countries.

On the basis of $F$ test, which says if $F^{*}$ (tabled value) $>F$ (calculated value) we accept the null hypothesis, we accept that the difference between the means is significant. From this evidence we may infer that the populations, from which the samples are drawn, do differ.

In this model calculated $F$ value is 9.782(India) and 21.139 (China) which is more than the critical value (4.49), we reject the null hypothesis. We can say that current health expenditure (\% of GDP) predict a significant amount of variance in labor's productivity in both the countries and the overall model is significant.

Thus, the increase in health expenditure needs to be on par with that of developed nation and needs to be supported by responsible governance and transparent handling of the public sector health funds, efforts to increase the wage levels of the population and finally, improvement of sanitation by government and private initiative.

\section{CONCLUSION}

The human capital formation is associated with the investment in man and his development as a creative and productive resource. Hence, human capital formation is a vital requirement for underdeveloped and developing countries if they want to achieve rapid progress. The recent literature in development economics demonstrates the increasing trend of developing countries starting to invest heavily in social sector programs, namely health, fertility control and education. The shifts in the patterns of public health expenditure represent one of the most effective techniques within the state power to improve the condition of the poor. Thus, for a nation to develop faster, it needs to provide primary health care services, along with adequate focus on secondary and tertiary health sectors. Several studies claim that in underdeveloped and developing countries like India, most of the people are uneducated or have a low literacy rate, majority of them being unskilled and untrained and their general health feeble. Thus, as is obvious from the above discussion, for the development of the country's vast human resources and in improving the quality of the life of the people, health is a necessary input.

\section{REFERENCES:}

1. Health and Development. World Health Organization.www.who.int

2. Rahman M.M., Khanam R.\& Rahman M. "Health care expenditure and health outcome nexus: new evidence from the SAARC-ASEAN region." Global Health.2018 Nov. 14(1):113. DOI: https://doi.org/10.1 186/s12992-018-0430-1

3. Sanghera T." Underinvesting in health, education is now risking India's economic future."2018 www. business-standard.com>Economy \& Policy $>$ News.

4. Jakovljevic M. Potapchik E. Popovich L. Barik D.\& Getzen T.E. "Evolving Health Expenditure Landscape of the BRICS Nations and Projection to 2025".2016 National Council of Applied Research, https://mpra.ub.uni-muenchen.de/77221/

5. Yadavar S. "Budget 2018: India's Healthcare Crisis Is Holding Back National Potential." India Spend. www.indiaspend.com>budget-2018-indiashealthcare-crisis-is -holding.

6. Murty, S. "Education, Health and Housing in India, some aspects." 2004, RBSA Publishers, Jaipur

7. Ullah S. Malik M.N. \& Hassan U.M. "Impact of Health on Labor Productivity: Empirical Evidence from Pakistan." European online Journal of Natural and Social Sciences, 2018, 8(1), pp 139-147. http//www.european. science.com > Home > Vol 8, No 1 (2019) > Ullah

8. Mohammadzadeh Y. Moradi M.\& Khezrian A. "Investigating the long -term relationship between health expenditure and labor productivity in Iran." Iran occupational health journal, 2019,16(2), 22-32. https://orcid.org/0000-0002-4364-5832.

9. Wang F. "More health expenditure, Better Economic Performance? Empirical Evidence from OECD Countries." Inquiry, 2015. www.ncbi.nim.nih.gov>pmc>articles>PMC5813635

10. Wei F.I. Xia Y. \& Kong Y. "Public Health Expenditure and Labor Productivity: A Tentative Interpretation Based on the Science of Brain Cognition".2018. DOI:10.14704/nq.2018.16.5.1274.

11. Serge M. P. \& Tieguhong J.C. "Health Expenditure and Economic Growth-a review of the literature and an analysis between the economic community for central African states (CEMAC) and selected African countries." Health Economic Review, 2017.

DOI:10.1186/s13561-017-0159-1. 
12. Dormont B.S. Pelgrin F. Oliveira J. \& Suhrcke M. "Health Expenditures, Longevity and Growth."2008

DOI:102139/ssrn.1130315 and

http://ssrn.com/abstract=1130315

13. Ercelik G. "The Relationship between Health

Expenditure and Economic Growth in Turkey from 1980

to 2015." Journal of Politics, Economy and

Management (JOPEM), 2018, 70(5), 129-

157.doi:10.1086/258730; OECD

14. Sarkar A. R. Sultana M. Mahumud R.A. Ahmed S. and others. "Effects of Occupational illness on labor productivity: A socioeconomic aspects of informal sector workers in urban Bangladesh." Journal of Occupational health,2016, 58(2),209-215.

https://www.ncbi.nlm.nih.gov/pmc/articles/PMC5356

15. Isreal A. I. O. Kalippan S.R. \& Hamzah H. Z. "Impact of Health Capital on Total Factor Productivity in Singapore." Journal Ekonomi Malaysia, 2019, 53 (2), 117 http://dx.doi.org/10.17576/JEM-2019-5302-7

16. Matthew, A.C. \& Neumayer, E. "The impact of poor health on total factor productivity." Journal of Development Studies, 2006, 42(6), 918-938 DOI:10.1080/00220380600774681.

17. Arun J. V.\& Kumar D. "Public health expenditure of BRICS countries - an empirical analysis." International Journal of Medical Science and Public health, 2016,5(11), 2212-2216.DOI: 10.5455/ijmsph.2016.130

18. Isaksson A." Determinants of total factor productivity: a literature review." Research and Statistics Branch, Staff Working Paper, United Nations Industrial Development Organization,2007.

19. Bekedam H. "Investing in health is investing in India's growth." Health care Sabha 2016.www.who.int

20. Muysken J., Yetkiner I.H. \& Ziesemer T. "Health, Labor Productivity and Growth. Research Memorandum" 028, 1999, Maastricht University, Maastricht Economic Research Institute on Innovation and Technology (MERIT)

21. Global Health Expenditure Data base- World Health Organization, World Bank (2019) WHO (apps.who.int/nha/database)

22. World Development Indicators, Country comparable data on Development World Bank.wdi.worldbank.org. 